\title{
The Assessment of Problems and Practices of Human Resource Management in Wolaita Zone Secondary Schools
}

\author{
Fasika Fanta \\ Infolink University College, Wolaita Sodo, Po.Box 396, Ethiopia
}

\begin{abstract}
The major purpose of the study was to undertake the assessment of human resource management practices in general secondary \& preparatory schools of wolayta Zone, thereby to investigate as to how the current practices of HRM and to give recommendation for problems that may be identified so as to improve the existing situation. A descriptive survey method was employed to the current status of teaching staff management in the selected secondary \& preparatory schools. The required information was gathered through the use of questionnaire, interview and document analysis. Different models of tools like percentage, and average mean were used to make analysis of data obtained from the respondents under the study. The findings indicated that the selected schools faced problems due to inappropriate planning of the teaching staff which must be prepared in advance. Furthermore. REB, ZEO and WEOs lacked appropriate recruitment and selection procedures and much attention was not given to the secondary \& preparatory school teaching staff managing in general. Teacher were less informed or with no information about their strengths and weaknesses through performance appraisal process conducted periodically and low rate of usage performance appraisal result for further placement, rewards, promotion or punishment. As a result, there were high teaching staff turnover in the Zone.
\end{abstract}

DOI: $10.7176 / \mathrm{EJBM} / 12-13-07$

Publication date:May $31^{\text {st }} 2020$

\subsection{Background of the study}

For any organization, provision of available resources is required to attain in its desired goals particularly; this may include human resources, materials and financial resources and time resources. Among these resources, human resources is of great important for the success of any organization. Thus, human resources are assets without which any organization could not realize its potential. It should be noted here that resources require further development to enhance growth, through education, which is regarded as a very important factor of human development. As stated in the Ethiopian education and training policy (1994: 7) Bring up citizens who can take care of and utilize resources wisely, who are trained in various skills by raising the private and social benefits of the education, along with this, it directs that there be appropriate nexus between education, training, research and development though coordinated participation among the relevant organization. Many scholars in the field of the study posit that the value of human resource remains indispensable for the achieving the desired results.

There are number of factors that contribute towards the success of an organization. These factors include capital equipment and man power and so on. Even if those all factors are important the human factor in the most significant one, since it is the people that use all other resources without the productive efforts of workers, the material resources on institution would be of no use.

Furthermore if the people who are in charge of these resources are not sufficiently qualified, then utilization of these resources would not be optimal(Chandan 2003: 272), From the various resources of an organization, none is as critical to the success of its undertakings as its human wealth, It is the human resources that supply the talent, skills and creativity to an organization, Their efforts and leadership to effective and efficient utilization of other resources would contribute much for the successful realization of desired organizational objectives ( Melaku, 1992;2)

\section{2 statement of the problem}

Among the staff personnel in the education system, teachers are the supreme factor because they are critically involved in the operation of school activities. Any other resources such as special buildings, costly equipment and sound syllabus will serve some useful purpose only when teachers involved to the nobility of the profession and its accompanying responsibilities. Successful and effective schools directly depended on the success and effectiveness of those who work in them. Hence, it should be noted here that the quality performances in the school system are to be developed and maintained, carefully attention should be also a given to effective personnel management. Of the teaching staff ( Aggarawal 1995: 395).

The researcher stabilizing the scholar mentioned the above idea in regarding to HRM practices \& problem in any organization, weather it is a school or another would have defined goals set to achieve and require resources to attain the objectives. Resources may be composed of technical, financial, material, human etc. To achieve the desired goals, the human resources component is primary and fundamental resource to all organizations. When it comes to schools particularly, the academic staff might be the first to be addressed with 
provision of teaching skilled workforce.

\section{3 objectives of the Study}

The general objectives of this study was to assess the underlying problems in the practices of HRM in Wolaita zone secondary school so as to forward viable recommendation based on the identifies the gap, specially the study has tried.

\section{Specific objectives}

$>$ To assess the extending and scope of human resources management level and its activities at zone, Woreda and school levels.

$>$ To examine the intensity of teachers requirement and selection practices the recruiter bodies and the participation of school principals in the activities.

$>$ To examine the extent to which teaching staff appraisal is conducted so or to improve the teaching learning activities of the school.

$>$ To point out major problems faced with teaching staff development and work relation of secondary school and Woreda education offices as well as zone education office.

$>$ To give feasible recommendations on ways through which the zones secondary schools of HRM is enhanced.

\section{Literature review}

Human Resource Management as a practice is perhaps as old as human kind. As a field of study, it is relatively new. Human resource management did not evolve in one smooth movement. It rather has gone through a serious historical event to reach its current level of development.

In support of this, Barry (2001:4) has stated that the precise origins of what we would understand by human resource management (HRM) can be debated. It can be argued that it originated the first time that any group of people were organized to achieve a common purpose. In term of modern HRM, at least in UK, the beginning of the professional function is generally viewed as the pre-world war II welfare officer. In the 1950's and 1960s personnel managers began to be appointed and establishment officers in the public sector.

The human resource management function has become increasingly important in today's fast changing world. Several trends, such global competition, technological dynamics, increasingly knowledgeable and sophisticated customers and more educated workforce, are all forcing companies to organize more responsively (Chandan,2003:272).

As further explained by Gomez-Mejie (2003:40), currently, the size of the typical Human Resource Department in the organization has been increased considerably. This increase reflects both the growth and complexity of government regulations and a great awareness that human resource issues are important to the achievement of business objectives.

The above argument attests to the condition of HRM practices in many schools across SNNPR state in Ethiopia. Thus, the writer believes that a proper management of teaching staff in a school is crucial for all rounded development of schools, which in turn contributes to the development of the educational sector at the national level. Such a situation requires proper human resources planning, selecting and recruitment of the teaching staff, proper performance appraisal, appropriate utilization of the available teachers, and an effective strategy for the professional development of teacher educators.

\section{RESEARCH DESIGN AND METHODOLOGY}

To undertake this study, Descriptive survey method will be employed. Descriptive research will be used to collect information about the current problems related to conduct the human resource management activities in the sampled secondary schools, woredas and zone education offices, since it examines a situation as it is. Besides, descriptive research helps to describe and interpret the trend of events that exist now and exist in the past and that have influences on the present (Leedy,2005; Ayalew, 198917 and Koul. L. 1984;402)

In this study the student researcher were use two sources of data. The primary and secondary sources of data. The primary data will be obtained from principals, vice principals, teachers, supervisors, woreda education officers non-teaching staffs whom are providing support for instructional process in school. The secondary sources of data will be gathered from pertinent document of strategic planning of schools, annual planning, annual school reports and relevant documents.

The sample elements of the be drawn by the techniques of purposive and the availability sampling in order to include all items of composition in to the sample size. By doing this, the researcher will have reliable and adequate information on the issues under study. Regarding the selected study area out of mentioned 4 woredas and 3 town administration 18 secondary schools. In these secondary schools there are 35 principals and 728 teacher and 254 support staff are working. The following (table: 1 ) shows the total and sample population of teachers in the study with their respective schools and weredas. 


\section{Data presentation, analysis and interpretation}

This part of the thesis deals with the presentation, analysis and interpretation of the data gathered from the sample of secondary schools, Woreda Education offices ( WEOs), Zone Education Office (ZEO) of the SNNPR state. The data obtained through questionnaires, interview and documents review were analyzed and interpreted.

\subsection{Characteristics of the Population Under Study}

In order to maximize varieties of the study groups, different categories of respondents were involved in this study as mentioned earlier. Therefore, it is believed that the responses and other relevant data were organized and analyzed in order to determine the outcome of the

study.

\begin{tabular}{|c|c|c|c|c|c|c|c|c|c|c|}
\hline \multirow{3}{*}{ No } & \multirow{3}{*}{\multicolumn{2}{|c|}{ Item }} & \multicolumn{8}{|c|}{ Respondents } \\
\hline & & & \multicolumn{2}{|c|}{$\begin{array}{l}\text { Teachers } \\
(75 \%)\end{array}$} & \multicolumn{2}{|c|}{$\begin{array}{l}\text { Educational } \\
\text { experts and } \\
\text { personnel } \\
\text { (woreda) } 18 \%\end{array}$} & \multicolumn{2}{|c|}{$\begin{array}{l}\text { Educational } \\
\text { experts and } \\
\text { personnel } \\
\text { (Zone) } 7 \%\end{array}$} & \multicolumn{2}{|c|}{ Total } \\
\hline & & & No & $\%$ & No & $\%$ & No & $\%$ & No & $\%$ \\
\hline \multirow[t]{3}{*}{1} & \multirow[t]{3}{*}{ Sex } & Male & 110 & 73.4 & 30 & 83.4 & 10 & 71.5 & 150 & 75 \\
\hline & & Female & 40 & 26.6 & 6 & 16.6 & 4 & 28.5 & 50 & 25 \\
\hline & & Total & 150 & 75 & 36 & 18 & 14 & 7 & 200 & 100 \\
\hline \multirow{6}{*}{2} & \multirow{6}{*}{$\begin{array}{l}\text { Age } \\
\text { In } \\
\text { year }\end{array}$} & $\begin{array}{l}20 \text { and } \\
\text { below }\end{array}$ & & & & & & & & \\
\hline & & $21-30$ & 24 & 12 & 3 & 1.5 & 2 & 1 & 29 & 14.5 \\
\hline & & $31-40$ & 60 & 30 & 18 & 9 & 7 & 3.5 & 85 & 42.5 \\
\hline & & $41-50$ & 48 & 24 & 10 & 5 & 2 & & 60 & 30 \\
\hline & & $\begin{array}{l}51 \text { and } \\
\text { above }\end{array}$ & 18 & 18 & 5 & 2.5 & 3 & 1.5 & 26 & 13 \\
\hline & & Total & 150 & 75 & 36 & 18 & 14 & 7 & 200 & 100 \\
\hline \multirow{6}{*}{3} & \multirow[t]{6}{*}{ Qualification } & Certificate & & & & & & & & \\
\hline & & Diploma & & & & & & & & \\
\hline & & $\mathrm{BA} / \mathrm{BSC}$ & 140 & 70 & 36 & 18 & 9 & 4.5 & 185 & 92.5 \\
\hline & & MA/MSC & 10 & 5 & & & 5 & 2.5 & 15 & 7.5 \\
\hline & & Others & & & & & & & & \\
\hline & & Total & 150 & 75 & 36 & 18 & 14 & 7 & 200 & 100 \\
\hline \multirow{6}{*}{4} & \multirow[t]{6}{*}{$\begin{array}{l}\text { Service } \\
\text { year }\end{array}$} & $\begin{array}{l}5 \text { and } \\
\text { below }\end{array}$ & 12 & 8 & - & & & & 12 & 7 \\
\hline & & $6-10$ & 34 & 22.6 & 3 & 1.5 & 1 & .5 & 38 & 19 \\
\hline & & $11-15$ & 63 & 42 & 3 & 1.5 & 2 & 1 & 68 & 34 \\
\hline & & $16-20$ & 26 & 17.4 & 28 & 14 & 7 & 3.5 & 61 & 30.5 \\
\hline & & $\begin{array}{ll}21 & \text { and } \\
\text { above } & \end{array}$ & 15 & 10 & 2 & 1 & 4 & 2 & 21 & 9.5 \\
\hline & & Total & 150 & 75 & 36 & 18 & 14 & 7 & 200 & 100 \\
\hline & & & & & & & & & & \\
\hline
\end{tabular}

AS it can be observed from table -one the majority $73.4 \%$ (110) of teachers $83.4 \%$ (30) of woreda $71.5 \%(10)$ of zonal education office experts and personnel were found to be males. The grand total sex 75.5 (152) of the respondents were male $23.1 \%$ (48) were females. This may indicate that the participation of female in the area was low. Thus, the respondents of the subject in this study have represented predominantly males' idea. It also indicate that the female participation and employment rate to the teaching profession in secondary schools woreda and zone education offices has been low. Moreover, the proportion of their representation in study take the same pattern.

With respect of age category, as shown in table, $15.7 \%$ (26) of the respondents fall the age of 51 and above $17.1 \%$ (29) of them fall with the age range of $21-30$, The remaining $46.6(85)$ and $24.7 \%$ (60) of the respondents were within the age range of 31-40 and 41-50 respectively. From the table one can understand the most of respondents were matured enough, since they are found in the group and their responses could be dependable.

As far as item three of table 2 concerned $0 \%$ of respondents or there were no certificate and diploma. From this data we understand that $93.3 \%$ (140) of teachers staff were degree 6.7\% (10) were MA/Msc the teaching staff have the required qualification to teach secondary school level, according to the established standard of the Ministry of Education. Concerning the educational experts and personnel from the same table all of the woreda respondents $100 \%$ (36) of them were degree level. When we come to the educational experts of zone level $64.2 \%$ (9) of them were degree and 35.8\% (5) of them were MA/Msc holders. 
In relation to service years as depicted in item four of table II the majority $42 \%$ (63) of teachers $8.4 \%$ (3) of woreda experts $14.2 \%(2)$ of zone experts have served between 11-15 years. The remaining $17.4 \%(26)$ teachers, $77.7 \%$ (26) of woreda experts and 50\% (7) of zone experts have served $16-20$ years. The remaining respondents $22.6 \%$ (34) teachers, 8.4\% (3) wereda experts and 7.2\% (1) of zone experts served 6-10 years. The others $10 \%$ (5) 0 f teachers, $5.5 \%$ (2) of wereda experts and 28.5 (4) of zone experts have served 21 years and above. Again $8 \%$ (12) of teachers have served 5 years and below.

As can see from the data, majority of teachers and educational experts have adequate teaching experiences and the administrative skills in the area they have been entitled to undertake their assignment.

\subsection{Analysis of the current Human Resource Management Practices Human Resource Planning}

The management of academic staff bases up on manpower planning for efficient and effective HRM. Man power planning in addition to the utilization of the existing teaching staff, aims at providing the school with relevant data related to educational background and work experience of a newly employed teaching staff. As mentioned in the part of literature review, manpower planning is the process which includes forecasting, developing and controlling by which an organization ensures that it has the right number of people and the right kind of people at the right place and the right time of doing work for which they are economically most useful.

Human resource planning is used to show the way of improving performance and providing greater job satisfaction. As stated by Meggision (1981:125) that the use of human resource plan as it provides the organization with people needed to perform the activities that will achieve the organization's goals. In this respect, the existing HRP practice of the sampled schools, offices and Bureau related to the HRP principles and the regional policies in the area was described based on the responses obtained on the following table.

Table: 2 Responses Given on Human Resource Planning Activities

\begin{tabular}{|c|c|c|c|c|c|c|c|}
\hline \multirow[t]{2}{*}{ No } & \multirow[t]{2}{*}{ Item } & \multicolumn{2}{|c|}{$\begin{array}{l}\text { Wereda education } \\
\text { officials }\end{array}$} & \multicolumn{2}{|c|}{$\begin{array}{l}\text { Zone education } \\
\text { officials }\end{array}$} & \multicolumn{2}{|c|}{ Total } \\
\hline & & No & $\%$ & No & $\%$ & No & $\%$ \\
\hline \multirow{4}{*}{1} & $\begin{array}{l}\text { Strategic thinking in HRP Practices } \\
\text { a) Low }\end{array}$ & 13 & 36.1 & 6 & 42.8 & 19 & 40 \\
\hline & b)Moderate & 12 & 33.3 & 5 & 33.3 & 17 & 34 \\
\hline & C)High & 11 & 30.5 & 3 & 21.4 & 14 & 26 \\
\hline & Total & 36 & 100 & 14 & 100 & 50 & 100 \\
\hline \multirow{4}{*}{2} & $\begin{array}{l}\text { Availability of skilled manpower in HRP } \\
\text { activities } \\
\text { A)Low }\end{array}$ & 12 & 33.3 & 8 & 57.2 & 20 & 45.2 \\
\hline & b)Moderate & 13 & 36.2 & 3 & 21.4 & 16 & 28.8 \\
\hline & c)High & 11 & 30.5 & 3 & 21.4 & 14 & 26 \\
\hline & Total & 36 & 100 & 14 & 100 & 50 & 100 \\
\hline \multirow[t]{2}{*}{3} & $\begin{array}{l}\text { Trained manpower need assessment that has } \\
\text { been done so far for secondary schools } \\
\text { a)Low } \\
\text { B)Moderate } \\
\text { c)High }\end{array}$ & $\begin{array}{l}13 \\
12 \\
11 \\
\end{array}$ & $\begin{array}{l}36.2 \\
33.4 \\
30.5 \\
\end{array}$ & $\begin{array}{l}7 \\
4 \\
3 \\
\end{array}$ & $\begin{array}{l}50 \\
28.5 \\
21.4 \\
\end{array}$ & $\begin{array}{l}20 \\
16 \\
14 \\
\end{array}$ & $\begin{array}{l}43.1 \\
30.9 \\
26\end{array}$ \\
\hline & Total & 36 & 100 & 14 & 100 & 50 & 100 \\
\hline \multirow{5}{*}{4} & $\begin{array}{l}\text { Attraction and retention of manpower in the } \\
\text { school based HRP activities }\end{array}$ & & & & & & \\
\hline & a) Low & 14 & 38.8 & 8 & 57.2 & 22 & 48 \\
\hline & b) Moderate & 12 & 33.4 & 3 & 21.4 & 15 & 27.4 \\
\hline & c)High & 10 & 27.8 & 3 & 21.4 & 13 & 24.6 \\
\hline & Total & 36 & 100 & 14 & 100 & 50 & 100 \\
\hline
\end{tabular}

As indicated in Table 2 the extent that the education sector activities concerning teaching manpower planning for secondary schools were exposed to the study groups to rate the items. Based on the responses obtained, each items of the table are analyzed as follows.

As it can be observed from the above table of item one, $40 \%$ (19) 0 f the total respondents agreed up on that 
the strategic thinking of teaching staff resource planning was low. Concerning this items, a large portion of the study groups $36.1 \%$ (13) of the wereda and $42.8 \%$ (6) of the zone educational experts and personnel confirmed that the application of the matter is low.

The existence of that conduct the activities of human resource planning at every level of educational institutions are very important. Based on this fact, responses were asked to rate the availability of skilled manpower to run HRP. Accordingly, 33.3\% (12) and 57.2\% (8) of educational experts and personnel from wereda offices and zone education office respectively replied regarding the availability of qualified man power that was low. On top of this, the interview held with head of educational offices and zone education offices conducted that one of the most critical problem in HRP activities were the unavailability of competent and trained manpower at each level of the education sector.

Pertaining to the need assessment that has been done so far for trained manpower for secondary school, as the proceeding item of the same table, the majority $43.1 \%$ (20) of the total respondents reported that the need assessment held was low. The rest 30.9\% (16) and 26\% (14) of them responded as moderate and high respectively. Therefore, based on the responses of the majority, it sounds logical to assume that the sampled educational sector under study, at every level, did not conduct teaching staff need assessment for secondary schools.

In the last item of Table 2, the sampled respondents were asked to rate the extent of attraction an retention of manpower in the school based HRP activities. To this effect, 38.8\% (14) and 57.2\% (8) of wereda education office and zone education office experts and personnel respectively, rated the attraction and retention of manpower in the based activities was low. These responses clearly showed that the attraction and retention of teaching staff in HRP practices so far has done was little.

\subsection{Recruitment and Selection of Teaching Staff}

As it discussed in the review of literature part, the first operation function of HRM is concerning with obtaining of proper kind and number of personnel necessary accomplish organizational goals. Procurement deals with determination of human resource recruitments and their recruitment, selection and placement, i.e. hiring and assigning of worker in the organization.

With this intention, the teacher was inspired to investigate how the recruitment of teaching staff employed currently in the sampled zone based on the following table. In an attempt to investigate whether the educational offices and zone education offices was recruited teaching staff for secondary school s following the recruitment steps and procedures, questions concerning recruitment were posed to werreda and zone Educational offices as well as for regional education bureau experts and personnel.

Table:3 Responses Given On Recruitment and Selection of Teachers

\begin{tabular}{|c|c|c|c|c|c|c|c|}
\hline \multirow[t]{2}{*}{ No } & \multirow[t]{2}{*}{ Item } & \multicolumn{2}{|c|}{$\begin{array}{l}\text { Wereda } \\
\text { education } \\
\text { officials }\end{array}$} & \multicolumn{2}{|c|}{$\begin{array}{l}\text { Zone } \\
\text { education } \\
\text { officials }\end{array}$} & \multicolumn{2}{|c|}{ Total } \\
\hline & & No & $\%$ & No & $\%$ & No & $\%$ \\
\hline \multirow[t]{2}{*}{1} & $\begin{array}{l}\text { Recruitment conducted based on HRP } \\
\text { a) Low } \\
\text { b)Moderate } \\
\text { c)High }\end{array}$ & $\begin{array}{l}14 \\
12 \\
10\end{array}$ & $\begin{array}{l}38.8 \\
33.3 \\
27.9\end{array}$ & $\begin{array}{l}7 \\
4 \\
3\end{array}$ & $\begin{array}{l}50 \\
28.5 \\
21.5\end{array}$ & $\begin{array}{l}21 \\
16 \\
13\end{array}$ & $\begin{array}{l}44.4 \\
30.9 \\
24.7\end{array}$ \\
\hline & Total & 36 & 100 & 14 & 100 & 50 & 100 \\
\hline \multirow[t]{2}{*}{2} & $\begin{array}{l}\text { Availability of skilled manpower to conduct teaching } \\
\text { staff recruitment and selection } \\
\text { a) Low } \\
\text { b)Moderate } \\
\text { c)High }\end{array}$ & $\begin{array}{l}13 \\
12 \\
11 \\
\end{array}$ & $\begin{array}{l}36.2 \\
33.3 \\
30.5 \\
\end{array}$ & $\begin{array}{l}5 \\
5 \\
4 \\
\end{array}$ & $\begin{array}{l}35.7 \\
35.7 \\
28.6 \\
\end{array}$ & $\begin{array}{l}18 \\
17 \\
15\end{array}$ & $\begin{array}{l}35.9 \\
34.5 \\
29.6 \\
\end{array}$ \\
\hline & Total & 36 & 100 & 14 & 100 & 50 & 100 \\
\hline \multirow[t]{2}{*}{3} & $\begin{array}{l}\text { Following the necessary steps, rules and policies in } \\
\text { recruitment and selection } \\
\text { a) Low } \\
\text { b) Moderate } \\
\text { c) High }\end{array}$ & $\begin{array}{l}14 \\
12 \\
10\end{array}$ & $\begin{array}{l}38.8 \\
33.4 \\
27.8\end{array}$ & $\begin{array}{l}8 \\
3 \\
3\end{array}$ & $\begin{array}{l}57 \\
21.5 \\
21.5\end{array}$ & $\begin{array}{l}22 \\
15 \\
13\end{array}$ & $\begin{array}{l}47.9 \\
27.5 \\
24.6\end{array}$ \\
\hline & Total & 36 & 100 & 14 & 100 & 50 & 100 \\
\hline \multirow[t]{2}{*}{4} & $\begin{array}{l}\text { System of advertising the existing vacancies } \\
\text { a) Low } \\
\text { b)Moderate } \\
\text { c) High }\end{array}$ & $\begin{array}{l}15 \\
11 \\
10\end{array}$ & $\begin{array}{l}41.6 \\
30.5 \\
27.9\end{array}$ & $\begin{array}{l}6 \\
4 \\
4\end{array}$ & $\begin{array}{l}42.8 \\
28.5 \\
28.6\end{array}$ & $\begin{array}{l}22 \\
14 \\
14\end{array}$ & $\begin{array}{l}42.3 \\
29.4 \\
28.3\end{array}$ \\
\hline & Total & 36 & 100 & 14 & 100 & 50 & 100 \\
\hline
\end{tabular}




\begin{tabular}{|c|c|c|c|c|c|c|c|}
\hline \multirow[t]{2}{*}{ No } & \multirow[t]{2}{*}{ Item } & \multicolumn{2}{|c|}{$\begin{array}{l}\text { Wereda } \\
\text { education } \\
\text { officials }\end{array}$} & \multicolumn{2}{|c|}{$\begin{array}{l}\text { Zone } \\
\text { education } \\
\text { officials }\end{array}$} & \multicolumn{2}{|c|}{ Total } \\
\hline & & No & $\%$ & No & $\%$ & No & $\%$ \\
\hline \multirow[t]{2}{*}{5} & $\begin{array}{l}\text { The degree of employing qualified teachers } \\
\text { a) Low } \\
\text { b)Moderate } \\
\text { c)High }\end{array}$ & $\begin{array}{l}16 \\
10 \\
10\end{array}$ & $\begin{array}{l}44.4 \\
27.8 \\
27.8\end{array}$ & $\begin{array}{l}8 \\
3 \\
3\end{array}$ & $\begin{array}{l}57.1 \\
21.5 \\
21.5\end{array}$ & $\begin{array}{l}24 \\
13 \\
13 \\
\end{array}$ & $\begin{array}{l}50.7 \\
24.6 \\
24.7 \\
\end{array}$ \\
\hline & Total & 36 & 100 & 14 & 100 & 50 & 100 \\
\hline \multirow[t]{2}{*}{6} & $\begin{array}{l}\text { Using appropriate selection technique like } \\
\text { educational level, GPA, working experience, giving } \\
\text { of test and interview etc } \\
\text { a)Low } \\
\text { b)Moderate } \\
\text { c)High }\end{array}$ & $\begin{array}{l}10 \\
13 \\
15\end{array}$ & $\begin{array}{l}27.9 \\
36.1 \\
41.6\end{array}$ & $\begin{array}{l}4 \\
6 \\
3\end{array}$ & $\begin{array}{l}28.5 \\
42.8 \\
21.5\end{array}$ & $\begin{array}{l}14 \\
19 \\
18\end{array}$ & $\begin{array}{l}28.2 \\
39.5 \\
31.6\end{array}$ \\
\hline & Total & 36 & 100 & 14 & 100 & 50 & 100 \\
\hline
\end{tabular}

As depicted in the Table 3 of item one, the respondents asked to rate whether the recruitments of teaching staff conducted based on pre-exist human resource plan or not. The majority of respondents $44.4 \%$ (21) of the total respondents reported that the recruitment conducted in the absence of pre-determined plan. The rest $30.9(16)$ and $24.7 \%$ (13) of the respondents have reported respectively that it was moderate and high. Subsequently, as the majority of respondents underlined on the issue that the recruitment was conducted in the absence of human resource plan. this has revealed the poor existing system of the educational sector concerning the matter at each level of hierarchy in the area under the study.

In item two of the same table, the question of the availability of skilled manpower to conduct the teaching staff recruitment and selection was asked the respondents in order to rate them. Accordingly 34.5\% (17) and 29.9\% (15)of the total respondents witnessed that the availability of skilled manpower was moderate and high respectively.

On the other hand, the substantial amount 35.95 (18) of the total respondents reported that the availability of skilled manpower to run the teaching staff recruitment and selection activities were low. Besides the above responses, the interview held with the school principals, wereda and zone heads of Education offices officials confirmed that there was a shortage of trained and skilled manpower at every level of the education sector.

With regard to item three of the same table, the respondents were requested whether the recruiters following necessary steps, rules and personnel policies in recruitment or not. Accordingly, considerable amount 47.5\% (22) of the total respondents said that necessary steps, and policies were not followed in conducting recruitment of teaching staff. The rest $27.5 \%$ (15) and $24.6 \%$ (13) of them reported that following the steps were moderate and high respectively. As a result, from this data, it can be inferred that the recruiters of teaching staff at every level of the education sector, from the regional bureau to wereda Education offices might not following the necessary steps, the existing Regional civil service commission rules and personnel policies of recruitment and selection.

Pertaining the advertising system, the existing vacancies in schools within the zone, both the study groups were asked to show their degree of agreement. In view of that, the small majority $28.3 \%$ (14) of the total respondents have reported that the existing system was high. On the other hand, a great majority $42.3 \%(22)$ of the total respondents witnessed that the existing system of advertizing was low. The rest, 29.4\% (14) of respondents were agreed that it was moderate. Therefore, based on the responses of the majority, it is fair to infer that either there was no existence of the system of teachers' position vacancy advertisement or even if it may exist its implementation was low.

Item five of the same table deals with the reaction of the two study groups in the request asked to rate the degree of employing qualified teachers during recruitment. As reported by $50.7 \%$ (24) of the total respondents negatively responded that the degree of employing qualified teachers during recruitment was low. The rest $24.7 \%$ (13) and $21.7 \%$ (11) of the total respondents reported that employing qualified teachers for secondary schools were moderate and high respectively. Thus, based on the responses of the majority, it is safe to infer that the degree of employing those qualified individuals that help the school educational goal was low.

As to the last item of the same table, the majority of respondents $39.5 \%$ (19) have responded that following the mentioned criteria for selection was moderate. On the other hand, few of the respondents $28 \%(14)$ of them have reported that the criteria for selection was low. Despite the fact that $31.6 \%$ (18) of the respondents confirmed that maintaining the procedure and criteria was high, implementation of the selection criteria at screening time in the sector seems moderate as confirmed by the majority above. On the contrary the witness obtained from open ended question imply that recruitment and selection teachers' promotion, and assignment were targeted at faithfulness and relationship to the administrative body. Recruitment and selection mostly conducted centrally at Zone Education Office or Regional Education Bureau without considering the local situation. These circumstances might created gap for administrator and ladder to force different hierarchy of education sector offices to run 
activities which affect the goals of education.

\subsection{Teachers' Performance Appraisal in Human Resource Management}

The purpose of teachers' performance appraisal include performance appraisal planning, task assignment, supervising/assisting, measurement, evaluation, feedback, control and the application of associated incentives. The sum of these elements constitutes the accountability system to which teachers are subjected in the execution of their job. At best, the performance appraisal management system includes the above mentioned elements as well as procedures that define and regulate areas of freedom, monitoring and evaluating, and rewards and penalties for once did in the institute. Subsequently, the accountability component of performance appraisal management may fail or be less effective if various elements of the above are missing, loss of not properly designed or enforced. In light of the above notion, the activities of teacher appraisal performance management system were investigated and analyzed based on the responses obtained from the respondents as described hereunder.

A Secondary school Appraisal Practice in Teachers' view

Table: 4 Views of Teachers on Teachers' Appraisal System

\begin{tabular}{|c|c|c|c|}
\hline \multirow[t]{2}{*}{ No } & \multirow[t]{2}{*}{ Item } & \multicolumn{2}{|c|}{$\begin{array}{l}\text { Respondents } \\
\text { (Teachers) }\end{array}$} \\
\hline & & No & $\%$ \\
\hline \multirow{5}{*}{1} & Teaching staff evaluation so as to improve teaching learning process & & \\
\hline & a) Low & 55 & 36.6 \\
\hline & b)Moderate & 49 & 32.7 \\
\hline & c) High & 46 & 30.7 \\
\hline & Total & 150 & 100 \\
\hline \multirow{5}{*}{2} & Teaching staff performance appraisal based on well established and clear criteria & & \\
\hline & a)Low & 56 & 37.3 \\
\hline & b) Moderate & 48 & 32 \\
\hline & c) High & 46 & 30.7 \\
\hline & Total & 150 & 100 \\
\hline \multirow{5}{*}{3} & Inform the strength and weakness of teaching staff through evaluation report & & \\
\hline & a) Low & 60 & 40 \\
\hline & b) Moderate & 49 & 32.7 \\
\hline & c) High & 41 & 27.3 \\
\hline & Total & 150 & 100 \\
\hline \multirow{5}{*}{4} & Appraisal results have been free from bias and favoritism & & \\
\hline & a) Low & 39 & 26 \\
\hline & b) Moderate & 61 & 40.6 \\
\hline & c) High & 50 & 33.4 \\
\hline & Total & 150 & 100 \\
\hline \multirow{5}{*}{5} & Placement of teachers based on their appraisal results & & \\
\hline & a) Low & 67 & 44.5 \\
\hline & b) Moderate & 30 & 20 \\
\hline & c) High & 53 & 35.5 \\
\hline & Total & 150 & 100 \\
\hline
\end{tabular}

The above table demonstrates the response for the question when and how the appraisal for the teaching staff was administered.

The first item of Table 4 shows, the view of teachers' appraisal system. To determine the contribution of appraisal in improving teaching learning process, the teaching staff of the secondary schools was asked to weigh up the evaluation of teachers in their respective schools in relation to the resultant improvement in the teaching learning process. Accordingly, 36.6\% (55) of teachers responded that teaching staff evaluation had low effect on improving teaching learning process. On the other hand, other teachers who were 49 in number $32.7 \%$ and (46) teachers $30.7 \%$ answered that teaching staff evaluation had moderate and high impact on improving overall teaching learning process respectively.

The respondent teaching staff was also asked about the basis of staff appraisal performance. The second item of the same table has indicated that 56 teacher $37.7 \%$ responded low level of establishment and clarity of criteria of staff performance appraisal. Whereas 48 teachers that constitute $32 \%$ of the respondent teachers, have indicated the moderate level of establishment and clarity of the existing evaluation criteria. The remaining teacher respondents, $30.7 \%$ (46) of them answered the question by saying it was high level.

The teachers' evaluation was also treated for the point of informing teachers' strengths and weaknesses in its overall report. With regard to this issue, item three of the above table revealed $40 \%(60)$ of the teacher respondents 
indicated that low level of informing teachers' strengths and weaknesses by the evaluation process. $32.7 \%$ (49) of the teachers have reported that as it to be moderate level. And the rest $27.3 \%$ (41) of the teachers revealed that teachers' evaluation inform about the strengths and weaknesses of the teaching staff highly.

The respondent teaching staffs was also asked to indicate the degree that the appraisal results have been free from biases and favoritism. As indicated on item four of Table vI, 26\% (39) of the teachers indicated that it was low degree and $40.6 \%$ (61) of the teachers indicated moderate degree of freedom form biases and favorites. The remaining $33.4 \%$ (50) of the teachers indicated that the appraisal results to be free from bias and favoritism at high level.

It is assumed that one of the outputs of the academic staff evaluation is promotion and/or placement of personnel at the right position. With regard to this point, item five of Table VI indicates that $44.5 \%$ (67) teachers said there was low rate of usage of teachers' appraisal in placement. Whereas, $20 \%(30)$ teachers replied there was moderate rate of placement of teachers base on their results and remaining, 35.5\% (53) said it was of high rate.

From these fact we can understand that majority of teachers respondents $36.6 \%$ (55) which was in number have indicated that teaching staff has low impact on improving the teaching learning process. almost the same number of respondents $37.3 \%$ (56) indicated that the clarity of criteria for teaching staff performance appraisal was low. In the same token, $40 \%$ (60) of the respondents indicated low level of capacity of the teachers' appraisal in informing strengths and weaknesses. The majority of respondents $40.6 \%$ (61) said that the evaluation process is free from bias and favoritism. Finally, 44.5\% (67) teachers indicated low effect of teachers' evaluation on their placements.

\subsection{The Current Teaching Staff Turnover and its Reason}

The following Table presents the opinion of respondents about teaching staff turnover. The absence of doing teaching staff reward based on their performance result, might be led the teaching staff mobilization. Based on this ground, the researcher initiated to identify whether or not the existence of teaching staff turnover and its reasons.

\section{Table : 5 Respondents view on Teaching Staff Turnover}

\begin{tabular}{|c|c|c|c|c|c|c|c|}
\hline \multirow[b]{3}{*}{ NO } & \multirow{3}{*}{ Item } & \multicolumn{6}{|c|}{ Respondents } \\
\hline & & \multicolumn{2}{|c|}{ Teachers } & \multicolumn{2}{|c|}{$\begin{array}{l}\text { Educational } \\
\text { experts and } \\
\text { personnel }\end{array}$} & \multicolumn{2}{|c|}{ Total } \\
\hline & & No & $\%$ & NO & $\%$ & No & $\%$ \\
\hline \multirow[t]{2}{*}{1} & $\begin{array}{l}\text { Is there any teaching staff turnover? } \\
\text { Yes } \\
\text { No }\end{array}$ & $\begin{array}{l}101 \\
49\end{array}$ & $\begin{array}{l}67.4 \\
32.6\end{array}$ & $\begin{array}{l}41 \\
9\end{array}$ & $\begin{array}{l}82 \\
18\end{array}$ & $\begin{array}{l}142 \\
58\end{array}$ & $\begin{array}{l}74.7 \\
25.3\end{array}$ \\
\hline & Total & 150 & 100 & 50 & 100 & 200 & 100 \\
\hline 2 & $\begin{array}{l}\text { Which level of teaching staff do turnover frequently? } \\
\text { A. Fresh } \\
\text { B. Middle } \\
\text { C. Senior } \\
\text { D. Middle and Senior } \\
\text { E. All }\end{array}$ & $\begin{array}{l}56 \\
11 \\
19 \\
16 \\
50\end{array}$ & $\begin{array}{l}36 \\
7.3 \\
12.6 \\
10.6 \\
33.5\end{array}$ & $\begin{array}{l}13 \\
3 \\
4 \\
9 \\
21\end{array}$ & $\begin{array}{l}26 \\
6 \\
8 \\
18 \\
42\end{array}$ & $\begin{array}{l}67 \\
14 \\
23 \\
25 \\
71\end{array}$ & $\begin{array}{l}31 \\
8 \\
10 \\
14 \\
37\end{array}$ \\
\hline \multirow{3}{*}{3} & Total & 150 & 100 & 50 & 100 & 200 & 100 \\
\hline & $\begin{array}{l}\text { If your response to Item } 2 \text { yes, what is the best reason for the } \\
\text { listed answers below? } \\
\text { A. Low Salary } \\
\text { B. Boss interference } \\
\text { C. Absence of reward for performance evaluation results } \\
\text { D. Low professional status }\end{array}$ & $\begin{array}{l}53 \\
12 \\
5 \\
80\end{array}$ & $\begin{array}{l}35.3 \\
8 \\
3.3 \\
53.4\end{array}$ & $\begin{array}{l}17 \\
8 \\
7 \\
18\end{array}$ & $\begin{array}{l}34 \\
16 \\
14 \\
36\end{array}$ & $\begin{array}{l}70 \\
20 \\
12 \\
98\end{array}$ & $\begin{array}{l}34.6 \\
12 \\
8.6 \\
44.8\end{array}$ \\
\hline & Total & 150 & 100 & 50 & 100 & 200 & 100 \\
\hline
\end{tabular}

Table: 5 above depicts respondents' perception of teaching staff turnover in selected secondary schools. As the item one from this table, the majority $74.7 \%$ the total respondents $(67.4$ percent of teachers and 82 percent of educational experts and personnel) have reported that there was a teaching staff turnover. The rest, 25.3 percent of the respondents ( 32.6 percent of teachers and 18 percent of educational experts and personnel) denied the existence of teaching staff turnover.

From the above data, only few respondents reported that as there was no human resource turnover. Documents assessed at zone education offices and interview held with school principals and educational officials revealed that, there was high rates of teachers' turnover in every school in the zone.

Further statistical analysis was used to test the significance difference input among the respondents in using them as a source of data input to the teaching staff turnover in the school. This perception difference might be due 
to either the educational experts and personnel have rarely recognized the movement of teaching staff or denied the turnover since its impact more revealed at secondary school than education office or bureau. No matter what the rational might be, despite the fact that the great amount of study groups, 74.7 percent (142) of the total respondents have reported that the existence of teaching staff turnover.

The second items of the same table, the respondents were requested to show the level of teaching staff that frequently left the job for various reasons.

Accordingly, the significant portion, 55.9 percent 84 of the total respondents reported that from all level teaching staff (fresh, middle and senior) teachers frequently left the school. On the other hand, a substantial portion of the respondents, 36 percent (54) reported that fresh teaching staff frequently left the school than others. This response also supported by statistical figure observed from document review in some of the sampled schools by the student researcher while conducting interview with the school principals.

For item three of the above table, those who agreed the existence of teaching staff turnover were further asked to specify their reasons. To this end, unexpectedly, only a very small portion 8.6 percent (12) of the total respondents replied that the absence of reward, the majority of the respondents 44.8 percent (98) reported that the best reason of teaching staff turnover was the status of teaching profession. On the other hand, some of the substantial portion of respondents 34.6 percent (70) reported that one of the best reasons for teachers' turnover was the low salary paid to the teacher for their profession.

\subsection{Provision of Training for Teaching Staff}

The kind of people required to the teaching staff of secondary school is a basic factor achieving the school objectives. Acquiring the required teachers by itself doesn't guarantee the attainment of school institutional goals. So it is essential for an institution to develop the teaching staff knowledge and skill to accomplish their job effectively to adopt them with the fast changes of technology as well as changes within the school institution.

Therefore, the target of the researcher was to identify how the teaching staff training and development considered and applied in the sampled secondary school. Based on this, the following tables are analyzed, considering the responses obtained on the current application of teaching staff training activities.

Table: 6 Responses Obtained On Teaching Staff Selection for Training

\begin{tabular}{|c|c|c|c|c|c|c|c|}
\hline \multirow{3}{*}{ No } & \multirow{3}{*}{ Item } & \multicolumn{6}{|c|}{ Respondents } \\
\hline & & \multicolumn{2}{|c|}{ Teachers } & \multicolumn{2}{|c|}{$\begin{array}{l}\text { Educational } \\
\text { experts and } \\
\text { personnel }\end{array}$} & \multicolumn{2}{|c|}{ Total } \\
\hline & & No & $\%$ & No & $\%$ & No & $\%$ \\
\hline \multirow[t]{2}{*}{1} & $\begin{array}{l}\text { Is there clear selection criteria for teachers' further education? } \\
\text { Yes } \\
\text { No } \\
\text { Not sure }\end{array}$ & $\begin{array}{l}80 \\
32 \\
38\end{array}$ & $\begin{array}{l}53.3 \\
21.3 \\
25.4\end{array}$ & $\begin{array}{l}29 \\
12 \\
9\end{array}$ & $\begin{array}{l}58 \\
24 \\
18\end{array}$ & $\begin{array}{l}109 \\
44 \\
47\end{array}$ & $\begin{array}{l}58.6 \\
22.7 \\
21.7\end{array}$ \\
\hline & Total & 150 & 100 & 50 & 100 & 200 & 100 \\
\hline \multirow[t]{2}{*}{2} & $\begin{array}{l}\text { The involvement of school principals in selection teaching } \\
\text { staff for training. } \\
\text { a) Low } \\
\text { b)Moderate } \\
\text { c) High }\end{array}$ & $\begin{array}{l}72 \\
36 \\
42\end{array}$ & $\begin{array}{l}48 \\
24 \\
28\end{array}$ & $\begin{array}{l}18 \\
20 \\
12\end{array}$ & $\begin{array}{l}36 \\
40 \\
24\end{array}$ & $\begin{array}{l}90 \\
56 \\
54\end{array}$ & $\begin{array}{l}42 \\
32 \\
26\end{array}$ \\
\hline & Total & 150 & 100 & 50 & 100 & 100 & 100 \\
\hline & $\begin{array}{l}\text { In the past two-to-three years most of the opportunities for } \\
\text { further training were obtained by/through } \\
\text { A. Regional education bureau } \\
\text { B. School effort } \\
\text { C. Personal effort } \\
\text { D. Zone/Woreda Education Office }\end{array}$ & $\begin{array}{l}48 \\
11 \\
24 \\
67 \\
\end{array}$ & $\begin{array}{l}32 \\
7.4 \\
16 \\
44.6 \\
\end{array}$ & $\begin{array}{l}26 \\
2 \\
10 \\
12 \\
\end{array}$ & $\begin{array}{l}52 \\
4 \\
20 \\
24 \\
\end{array}$ & $\begin{array}{l}74 \\
13 \\
34 \\
79 \\
\end{array}$ & $\begin{array}{l}42 \\
5.7 \\
18 \\
34.3 \\
\end{array}$ \\
\hline & & 150 & 100 & 50 & 100 & 200 & 100 \\
\hline
\end{tabular}

In table 6 items related to the training of teachers were considered. In response of item one, $55.5 \%(109)$ of the total respondents' confirmed that the selection criteria for teachers' further education was clear and transparent. However, a considerable portion $22.6 \%$ (44) have reported that the inexistence or inconsiderable of clear criteria to select teaching staff for further education. On the same issue $21.7 \%$ (47) of the total respondents reported that they were not sure whether clear selection criteria was in place or not. This by itself shows that lack of transparency while conducting the selection of teachers for further education or the absence of clear criteria at all. 
With regards to the opportunity obtained for further training for the last two-to-three years, $42 \%$ (74) of the total respondents agreed that the chance was obtained by the Regional Education Bureau (REB). On the other hand, $34.3 \%$ (79) of them reported that the opportunities were obtained by zone/wereda education offices. In this item effort of school, revealed that $5.7 \%$ (13) which is the least one when compared with other option. This may be due to the absence of appropriate and skilled educational managers at school level or lack of assigning the right person at the right position, it may need.

Whatever the reason it may be, despite the perceptual difference between the two study groups, the least amount of respondents $5.7 \%$ (13) of the total respondent confirmed that the school effort in finding the opportunities for further training of the teaching staff was low. On this matter interview with officials and school principals witnessed that the appropriate person or educational managers were not assigned to run the school activities. Therefore, this by implication endorses, that the effort of searching opportunities for further training of teachers in secondary schools was minimal.

From the same table above, with regards to school principal involvement in selecting teaching staff fro training, both groups of the study were asked to show their degree of agreement. Accordingly, the small minority, $26 \%$ (54) of the total respondents reported that the involvement of school principal in selecting teaching staff for training is high. On the other hand, a great majority $42 \%$ (90) of the total respondents refused to accept the idea. The rest which is $32 \%$ (56) of the total respondents agreed up the issue as on as it was moderate or fair. Consequently, it is clear to say from the data that, there was no such an involvement of school principals in teacher's selection for training. This idea was also supported by the data obtained through interview held with some heads of wereda Education offices and school principals.

\subsection{Provision of Teaching Staff Training}

Table : 7 view of Teachers on Provision of Training Situation in Their Respective schools

\begin{tabular}{|c|c|c|c|}
\hline No & 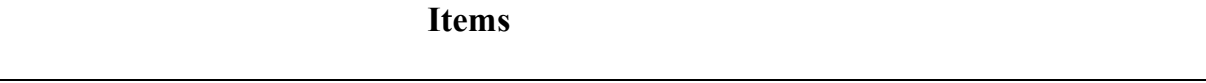 & $\begin{array}{l}\text { Res! } \\
\text { (Tea }\end{array}$ & $\begin{array}{l}\text { dents } \\
\text { rs) }\end{array}$ \\
\hline 1 & $\begin{array}{l}\text { Teachers' provision of professional improvement } \\
\text { a) Low }\end{array}$ & 57 & 38 \\
\hline & b) Moderate & 51 & 34 \\
\hline & c) High & 42 & 28 \\
\hline & Total & 150 & 100 \\
\hline 2 & $\begin{array}{l}\text { Training needs assessment conducted and its implementation } \\
\text { a) Low }\end{array}$ & 60 & 40 \\
\hline & b) Moderate & 45 & 30 \\
\hline & c) High & 45 & 30 \\
\hline & Total & 150 & 100 \\
\hline 3 & $\begin{array}{l}\text { Training compatibility with the position that the teacher holds } \\
\text { a) Low }\end{array}$ & 54 & 36 \\
\hline & b) Moderate & 60 & 40 \\
\hline & c) High & 36 & 24 \\
\hline & Total & 150 & 100 \\
\hline 4 & $\begin{array}{l}\text { On-the-job training given for teaching staff } \\
\text { a) Low }\end{array}$ & 92 & 61.3 \\
\hline & b) Moderate & 18 & 12 \\
\hline & c) High & 40 & 26.7 \\
\hline & Total & 150 & 100 \\
\hline 5 & $\begin{array}{l}\text { Off-the-job training given for teaching staff } \\
\text { a) Low }\end{array}$ & 33 & 22 \\
\hline & b) Moderate & 68 & 45.3 \\
\hline & c) High & 49 & 32.7 \\
\hline & Total & 150 & 100 \\
\hline 6 & $\begin{array}{l}\text { Practice of evaluating the training results on the work along with its effects and } \\
\text { changes that are exhibited. } \\
\text { a) Low }\end{array}$ & 69 & 46 \\
\hline & b) Moderate & 39 & 26 \\
\hline & C) High & 42 & 28 \\
\hline & Total & 150 & 100 \\
\hline
\end{tabular}

The above Table shows, the view of researcher's training provision situation, in selected secondary schools. Item one of table 9, tries to investigate that, to what extent teachers were provided with different professional 
improvement and training program to develop competency in their profession. With regard to this point, 38\% (57) teachers said, there was low level of professional improvement as a result of training offered to the teaching staff. 51 , teacher respondents which constitute $34 \%$ indicated moderate level and the remaining $28 \%$ (42) of the respondents said that there was high level of provision of professional improvement.

Item two of table 7, demonstrates the level of conducting training need assessment and its implementation. Here, majority of respondents $40 \%$ (60) responded that there was low level of conducting the needs assessment and $30 \%$ (45) of the implementation to be of moderate level. And the remaining $30 \%$ (45) of the respondents indicated it, to be of high level.

The third item of table 7 , which tries to analyze the compatibility of the training with current position of teachers $36 \%$ (54), said it was of low level of compatibility, 40\% (60) replied it was of moderate level of compatibility and the remaining $24 \%$ (36) stated it to be of high level of compatibility.

The process of investigating the rating scale of, on-the-job training and off-the-job training, were offered for the teaching staff. As of item four and five from the same table indicates, 61.3\% (92) of respondents demonstrated that of on-the-job training was low rate, and 12 percent (18) and 26.7\% (40) of respondents indicated moderate and high rate of on the job training respectively. On the other hand, $22 \%$ (33) of the respondents stated that there was low rate of off-the-job training and the remaining $45.3 \%$ (68) and $32.7 \%$ (49) of the respondents of the teaching staff indicated the rate of Off-the-job training to be moderate and high respectively.

With regard to evaluating the training results, on the work of the teaching staff, $46 \%(69)$ of respondents indicated that, there was low practice of evaluation the training programs in relation to the teaching staff job holder. $26 \%$ (39) of the respondents stated that moderate practice and the remaining $28 \%$ (42) said that, there was high practice of evaluating the training results, on work long with its effects and changes that were exhibited.

From the above facts presented on the table, we can understand that significant number of respondents $38 \%$ (57) of the respondents revealed that there was low level of professional improvement brought about via the training process offered to be teaching staff. Almost majority $40 \%$ (60) of the respondents also said the level of conducting and implementing needs assessment of training was low. With regard to the compatibility of the training 36\% (54) of respondents revealed it to be less compatible. 61.3\% (92) of respondents reported as low rating for on-the-job training of the teaching staff and 45.3\% (68) indicated moderate rate of the off-the-job training. Finally, with regard to the practice of evaluating the training program $46 \%$ (69) indicated it to be of low rating. Overall, with the exception of the compatibility training form the above analysis all items seek immediate rethinking in finding the necessary solution to get better teaching profession in the demonstrated zone.

\subsection{Summary of Findings, Conclusion and Recommendation}

In this section of the thesis the summary of major findings of the study, conclusions are drown on the basis of the research findings and recommendations that are assumed to be useful to tackle the problems are presented.

\subsection{Summary of Findings}

To meet the objective of the study stated earlier, this study had the four basic research questions raised in the debate. In dealing with the research questions related data were gathered mainly through questionnaire, interview and document review. The data obtained were analyzed and interpreted by using appropriate statistical instruments such as frequency distribution, percentage, chi-square, t-test and average mean. Based on the analysis made, the summary of the findings are organized below in five groups.

\subsubsection{Conclusion}

* Almost most of the respondents, $76.1 \%$ of these study group were male. This indicate that poor participation of female in the area. Therefore, the responses of the subject represented predominantly male' idea.

\# The majority, $46.6 \%$ and $24.7 \%$ of the respondents were within the age category of $31-40$ and $41-50$ respectively. This may indicate that most the respondents were matured enough and their responses could be useful for the study.

* About $93.3 \%$ of the total size of the teachers in the sampled zone have required qualification for secondary school teachers as a standard of Ministry of Education (MOE) or Regional Education Bureau.

* The Majority of teachers, educational experts and personnel have adequate teaching experience and administrative skills of educational systems in that order.

* Almost all respondents from Woreda and zone educational experts and personnel confirmed that the strategic thinking of HRP was minimal. One the reasons quoted for the strategic thinking in HRP was the shortage of skilled manpower as required number in the area.

* The respondents reported that the teaching staff need assessment conducted at each hierarchy of the educational sector for secondary schools was low.

* There were no adequate efforts that have been done so far in human resource planning in retention and attraction of well trained and experienced secondary school teachers.

\# The overall strategic thinking and plan that relating to the issue of HRP was inadequate. This is due to lack of 
capacity at school, woreda and zone levels, along with skilled human resource turnover on the area, less awareness on the importance of HRP and little attention that has been given to HRP at all levels of the education sector.

* Considerable portion of the respondents, i.e. $44.4 \%$ reported that recruitment of teaching staff conducted in the lower level pre-recruitment existing plan. The rest $30.9 \%$ and $24.7 \%$ of the respondents rated that there was moderate and high pre-recruitment plan respectively. From the sampled area, one can infer that poor or absence of pre-recruitment plan on those levels of the educational sector.

* The degree to which the availability of trained manpower to facilitate the activities of teaching staff recruitment and selection was found to below. Based on the existing necessary rules, regulations, steps and procedures in teaching staff recruitment and selection at every stage of the education sector was minimal. Advertisement of vacancies noticed in the zone for teachers' was low or it was rarely done.

It has been found that the degree of employing those qualified individuals that help the school educational goals attainment was low. It was found out that there were inappropriate recruitment and selection procedures due to less attention that was given to secondary school teaching staff managing in general. Recruitment and selection mostly conducted centrally at ZEO or REB without considering the local infrastructure situation.

\subsubsection{Recommendations}

In this section of the study, some recommendations are presented that will help decision makers in the area consider past shortcomings and to undertake corrective measures for the success of future accomplishments. On the basis of research findings and the conclusions drawn, the following recommendations are forwarded for further considerations and applications in the future of HRM practices in the region in general and the zone secondary and preparatory schools in HRM practices endeavors in particular .

$>$ It is generally acceptable both in principle and in practice that HRP is the bases of all tasks that would take place in other stages of any sequentially under taken HRM involvement. Before advancing to other phases, the target HRM personnel, school principals, educational experts and officials need to be adequately informed and remarked about the importance and working mechanisms of the anticipated HRM. This can certainly to examine which activities of HRM needed at the most and when it is applicable as well as get certain and implemented on a continuous and sustainable basis. This is being the like results of adequate and appropriate HRM is it will be applicable accordingly. Therefore, intensive awareness creation in the form of short-term training should be designed and given due emphasis in teaching staff resource planning for all concerned experts, personnel, school principals and officials by the regional education bureau to alleviate the identified problems in HRM.

$>$ In order to ultimately alleviate the problems encountered during recruitment and selection of teaching staff for secondary school, the school, woreda and zone education offices in collaboration with the regional education bureau should:

- Develop clear and transparent criteria and guidelines in which the functions and responsibilities of each entity demarcated or revise the existing one to the same case.

- Place qualified and experienced manpower that can handle the recruitment and selection process so as to employ qualified and competent teachers for secondary schools.

- Arrange short-term training programs on recruitment and selection for educational personnel that are found at all levels of education sectors in order to equip them with the necessary skills and commitment in the area.

- The REB needs to draw attention to the local level problems while conducting teacher recruitment and selection or should arrange a mechanism to decentralize these activities at the levels zone and woreda education offices.

\section{References}

AggarawolJ.c( 1995). Teacher education in a developing society: : New Delhi Uikas

Armstrong, P , and Dawson C. ( 1985) people in organization $3^{\text {rd }}$ ed . worchaster: Billings Ltd.

Att wood M. and Dimmock S. ( 1996) personal management New Delhi: crest publishing house.

Bamerjee, A, M , and Prasad, D ( 1985). Management of human resource.New Delhi sterling publisher pot.Ltd.

Castter, W.B. (1981) .the personal function in educational administration 3rded, new York; Macmillan campany.

Graham H.T and bennet, R ( 1990). Human resources management ; $6^{\text {th }}$ ed, bugaysalfolk : Richard clay Ltd

Henaman , Herbert G. and et al (1996 . personal : humans resource mangemnt . new yourk : Me graw - Hill international Book company

Monday . R.K. and R.M . ( 1990) human resource management ( $4^{\text {th }}$ ed.) Boston Allgn and Bacon.

Musaazi :- J.C.S ( 1988) . the theory and practice of educational administration : London; macmillan pubilisher Ltd.

Ramasay, T. ( 2005) principles of management ; New delhi Himalaya publishing house. Raston, S.D, ( 1996). The human side of management New Dolhi universal book staff. 
Saiyadain, M. S. (1988). Human resources management ; New Delhi tataMcgraw-hill publishing company limited Saxe R.w . 9 1980), Educational Administration to day .an introduction, Mccutchin publishing corporation .

Shermann, A, etal . ( 1996) managing human resource loth Np: south western college publishing.

South worth, G . (1990). Staff selection in primary school England : Basil Blak well LDT.

Starrat , J. ( 2002) supervision : A redefinition . New yourk MC- graw- hill publisher.

Stoops. E. et al ( 1981). Hand book of educational administration Aguidefor the practitioner $2^{\text {nd }}$ ed . Boston;Allygn and Bacon Inc.

Storcy, J.( 1995) Human resource management critical jert London: Rufledge

True love S. (2001), Training for Development - A hand book New Delhi maya publishers private Ltd.

Tyson.S .and York. A. (1996). Human resource management London liners house. 